\title{
Otolith morphology and body size relationships for juvenile Sciaenidae in the Río de la Plata estuary $\left(35-36^{\circ} \mathrm{S}\right)^{*}$
}

\author{
JUAN A. WAESSLE ${ }^{1,2}$, CARLOS A. LASTA ${ }^{1}$ and MARCO FAVERO ${ }^{2}$ \\ ${ }^{1}$ INIDEP - Instituto Nacional de Investigación y Desarrollo Pesquero, Paseo Victoria Ocampo № 1, P.O. Box 175 \\ 7600 Mar del Plata, Argentina. E-mail: jwaessle@mdp.edu.ar \\ ${ }^{2}$ Universidad Nacional de Mar del Plata, Facultad de Ciencias Exactas y Naturales, Departamento de Biología, \\ Funes 3250 (B7602AYJ) Mar del Plata, Argentina.
}

\begin{abstract}
SUMMARY: Seven species of the family Sciaenidae have been reported inhabiting bottom waters of the Río de la Plata estuary. Of these juvenile stripped weakfish (Cynoscion guatucupa), king weakfish (Macrodon ancylodon), whitemouth croaker (Micropogonias furnieri) and banded ground drum (Paralonchurus brasiliensis) are by far the most abundant. These species are also important prey of several top-predator species among large fishes, seabirds and mammals. In this study we provide new information regarding otolith morphology and body size relationships of juvenile sciaenid fish. The sagittae morphology of juvenile sciaenids showed strong changes in the course of their development (e.g. in overall shape and development of concrescences on the outer surface). Analysing the morphometric relationships, we concluded that otolith length and otolith mass are good indicators of fish standard length and fish weight in all species. If otolith length or mass is used to estimate fish length, the regression explained more than $97 \%$ of the variation in all species. All equations relating fish standard length and fish weight for juvenile stages of the species studied explained a very large proportion of the variance in the data. These data will help researchers studying food habits of top predators to determine size and weight of usually juvenile fish-prey from length, broad and/or weight of recovered otoliths.
\end{abstract}

Key words: otolith morphology, otolith morphometry, fish prey, Cynoscion guatucupa, Macrodon ancylodon, Micropogonias furnieri, Paralonchurus brasiliensis.

RESUMEN: MORFOLOGÍA DE OTOLITO Y RELACIONES DE TAMAÑO CORPORAL PARA ESCIÉNIDOS JUVENILES EN EL ESTUARIO DEL Río DE la Plata $\left(35-36^{\circ} \mathrm{S}\right)$. - Siete especies de la familia Sciaenidae son reportadas habitando aguas de fondo en el estuario del Río de la Plata, juveniles de pescadilla común (Cynoscion guatucupa), pescadilla real (Macrodon ancylodon), corvina rubia (Micropogonias furnieri) y córvalo (Paralonchurus brasiliensis) son por mucho los más abundantes. Estas especies son importantes presas de varias especies predadoras tope, entre ellas grandes peces, aves marinas y mamíferos. En este estudio se provee nueva información respecto a morfología de otolito y relaciones de tamaño corporal de esciénidos juveniles. La morfología de sagittae de esciénidos juveniles mostró fuertes cambios a través de su desarrollo (por ej. en la forma general y el desarrollo de concreciones en la superficie externa). Analizando las relaciones morfométricas, concluimos que el largo del otolito y la masa del otolito son buenos indicadores del largo standard y peso del pez en todas las especies. Si el largo del otolito o la masa son usados para estimar el largo del pez, la regresión explicará mas del 97\% de la variación en todas las especies. Todas las ecuaciones relacionando el largo standard del pez y el peso para estadíos juveniles de las especies estudiadas explicaron una gran proporción de la varianza de los datos. Estos datos ayudarán a investigadores que estudien hábitos alimenticios de predadores tope a determinar talla y peso de peces presa normalmente juveniles, con el largo, ancho y/o peso de otolitos recuperados.

Palabras clave: morfología de otolito, morfometría de otolito, peces presa, Cynoscion guatucupa, Macrodon ancylodon, Micropogonias furnieri, Paralonchurus brasiliensis. 


\section{INTRODUCTION}

The family Sciaenidae is important in both tropical and subtropical waters; sciaenid species are usually common and abundant in estuarine waters, which are often used for spawning of adult and growth of juvenile individuals (Corrêa and Vianna, 1993; Acha et al., 1999). Seven species of this family have been reported as inhabiting bottom waters of the Río de la Plata estuary $\left(34^{\circ}-36^{\circ} \mathrm{S}, 54^{\circ}-57^{\circ} \mathrm{W}\right)$. Of these juvenile stripped weakfish, Cynoscion guatucupa (Cuvier, 1830), king weakfish, Macrodon ancylodon Schneider, 1801, whitemouth croaker, Micropogonias furnieri (Desmarest, 1823) and banded ground drum Paralonchurus brasiliensis (Steindachner, 1875) are by far the most abundant (Cousseau, 1985; Lasta, 1995). These species are also important prey of top-predator seabirds, such as the common tern, Sterna hirundo (Linnaeus, 1758) (Mauco et al., 2001), the South American tern, Sterna hirundinacea (Lesson, 1831) (Favero et al., 2000a), the royal tern, Thalasseus maximus (Boddaert, 1783), the Sandwich tern, T. sandvicensis (Latham, 1787) (Favero et al., 2000b), the kelp gull, Larus dominicanus (Lichtenstein, 1823) (Silva et al., 2000) and the black skimmer, Rynchops niger (Linnaeus, 1758) (Favero et al., 2001). Among marine mammals, the South American sea lion, Otaria flavescens (Shaw, 1800), the South American fur seal, Arctocephalus australis (Zimmerman, 1783) (Rodríguez, 1996), and the franciscana dolphin, Pontoporia blainvillei (Gervais and d'Orbigny, 1844) (Brownell, 1975) are also important predators of these sciaenid fish.

The identification and quantification of fish species in the diet of top predators (marine mammals, fish and seabirds, among others) usually require the analysis and identification of diagnostic hard remains found in food samples. Particularly, sagittae otoliths recovered from digestive tracts, faeces and/or regurgitated scats of piscivorous animals have been extensively used for identification of prey (Granadeiro and Silva, 2000; Everson et al., 1999; Tollit et al., 1997; Corrêa and Vianna, 1993; White, 1991; Jobling and Breiby, 1986). The adequate identification of fish prey from otoliths is essential in feeding studies, where the relationship between otolith length and fish length or weight given by specific regressions can also be used to estimate the size and/or mass of prey (Harvey et al., 2000; Everson et al., 1999; Baldás et al., 1997; Reid, 1996; Corrêa and Vianna, 1993; Gamboa, 1991). Furthermore, fishery biologists have been using this information as an indirect indicator of fish distribution and also for quantifying the potential effects of natural predation (Corrêa and Vianna, 1993; Mauco et al., 2001).

The sagittae otoliths of each sciaenid species show typical morphology features, most of which have been studied by several authors in adult fishes (Volpedo and Echeverría, 2000; Baldás et al., 1997; Corrêa and Vianna, 1993; Torno, 1976). Nevertheless, information about the morphology and morphometry of otoliths in juvenile individuals is scarce, and only partial information is available on whitemouth croakers (Volpedo and Echeverría, 1999). The aim of this study was to provide new information regarding otolith morphology and body size relationships of juveniles of the four most abundant sciaenids in the Río de la Plata estuary: $C$. guatucupa, $M$. ancylodon, $M$. furnieri and $P$. brasiliensis. These data might be used by researchers studying food habits of top predators to determine the size and weight of juvenile fish-prey from length, width and/or weight of recovered otoliths. We also provide new otolith images from juvenile fish, usually away from adult morphology, to be used as and aid for identifying fish species.

\section{MATERIALS AND METHODS}

Fishes were collected from December 1999 to December 2000 using a beach seine designed for capture of post-larval and juveniles (mesh $=5 \mathrm{~mm}$ ) during fishing research cruises in the estuary of the Río de la Plata. Samples were preserved in 98\% ethanol until examination. Fishes were identified following keys provided in Menni et al. (1984). Standard length (SL, from the most anterior point to the base of hypural plate at caudal flexion) was measured to the nearest $\mathrm{mm}$ and fish were weighed to $0.01 \mathrm{~g}$ using a digital scale (Mettler PC 2000).

Sagittae were removed, cleaned, and stored dry for subsequent examination. Maximum otolith length (OL) and width (OW) were measured using a binocular magnifier (OLYMPUS $52 \mathrm{H} 10,10 \mathrm{X}$ ) and RATOC otolith image analyser program version 3.0. Total otolith mass (OM) was weighed using a standard analytical scale to the nearest $0.1 \mathrm{mg}$. Sagittae were described following Volpedo and Echeverría (2000) and Baldás et al. (1997). The following characters were analysed: overall morphology and dif- 


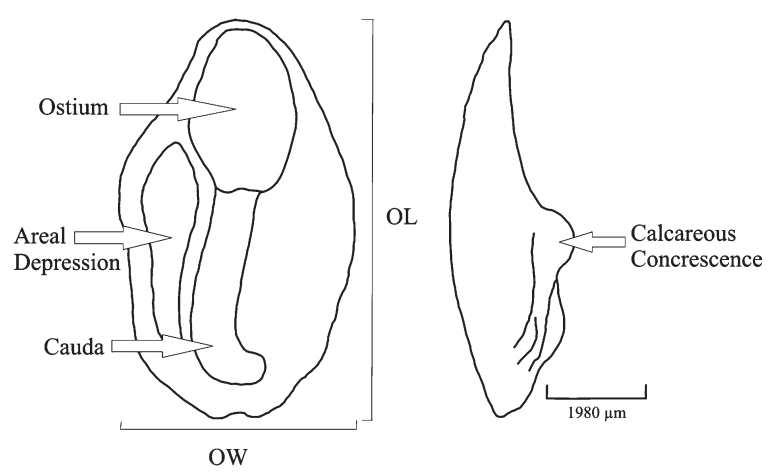

FIG. 1. - Terminology used throughout the text in the descriptions of otoliths of four sciaenid species from the Río de la Plata estuary. Left: view from inner side, right: dorsal view, anterior is up.

ferent types of marginal sculpture, mainly dorsal and ventral margins, differences in the levels reached between the ostium and the cauda, presence and absence of a dorsal areal depression, calcareous concrescence and curvature of the otolith (Fig. 1).

Differences between right and left sagittae were tested using a paired $t$-test. The following morphometric relationships were analysed: fish weight $(\mathrm{W})$ vs. SL, OL vs. SL, OW vs. SL, otolith total mass
(OM) vs. SL, OL vs. W, OW vs. W, and OM vs. W. Morphometric relationships were built using potential regression models which best fit the data distribution.

\section{RESULTS}

\section{Morphological analysis}

Based on changes observed in otolith morphology and following the criteria given by Volpedo and Echeverría (1999), we distinguished three otolith categories according to otolith growth: category I includes fishes from 30 to $60 \mathrm{~mm} \mathrm{SL}$, category II includes those from 70 to $110 \mathrm{~mm} \mathrm{SL}$, and category III includes fishes from 120 to $170 \mathrm{~mm}$.

Stripped weakfish (Fig. 2A): overall morphology changed from polygonal in category I to oblong with angular front zone in category II, and far oblong in category III. Margins were sinuate in category I, and entire from category II onwards. Cauda was curved
A
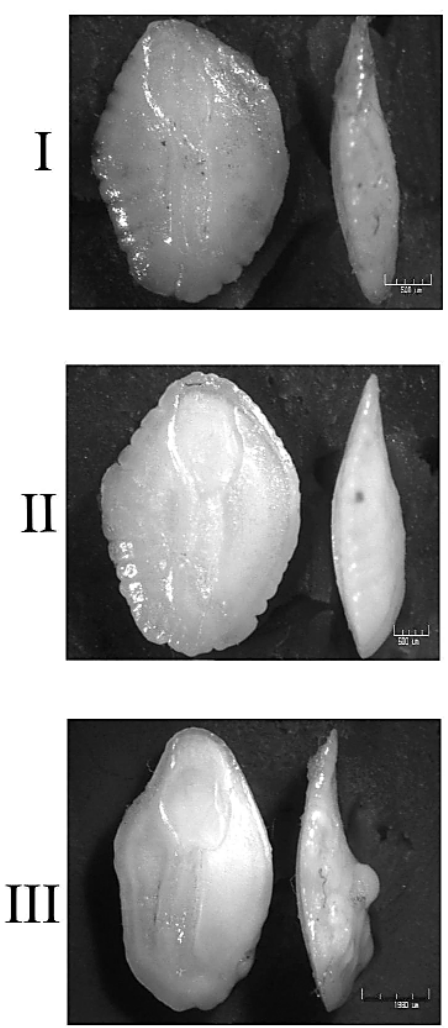

B
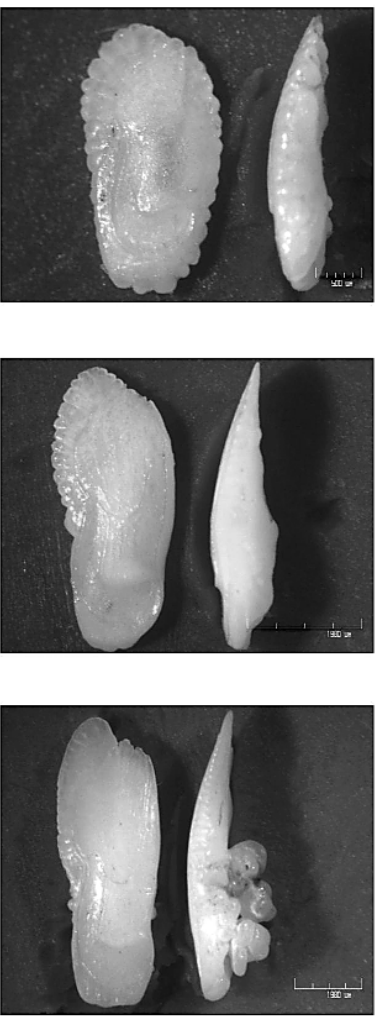

$\mathrm{C}$
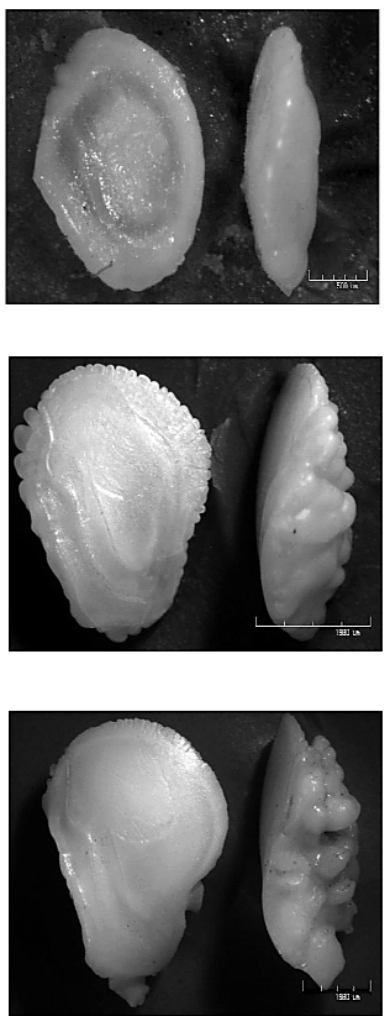

$\mathrm{D}$
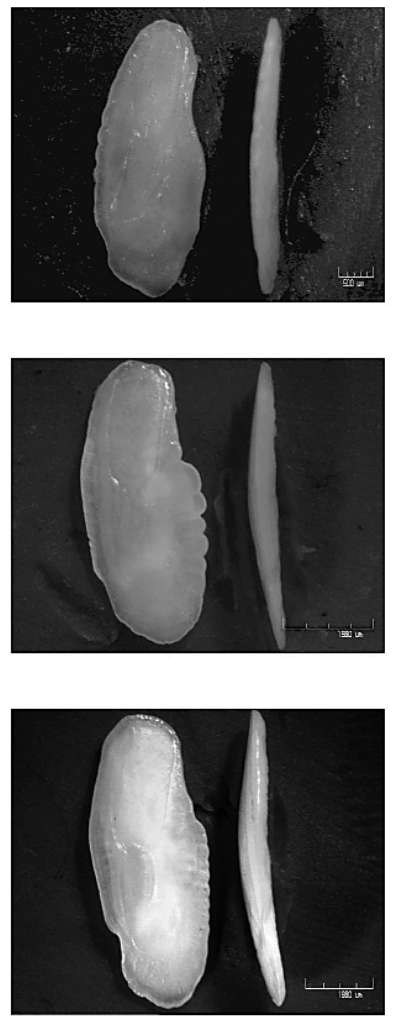

FIG. 2. - Otolith morphology of stripped weakfish (A), banded ground drum (B), whitemouth croaker (C) and king weakfish (D) through categories I (30-60 mm SL), II (60-110 mm SL) and III (110-170 mm SL). In each picture lateral view from inner side is an otolith left and dorsal view is at right, anterior is at top. Scale bar is $0.5 \mathrm{~mm}$ for all pictures of category I and AII; and $1.98 \mathrm{~mm}$ for BII, CII, DII, and all pictures of category III. 
to ventral margin in all categories; ostium and cauda were at the same level in category I but the latter was much deeper than the former in categories II and III. Only category III showed calcareous concrescence at the back of the outer face. The inner face was convex, mainly in otoliths of categories II and III. All categories presented dorsal areal depression.

Banded ground drum (Fig. 2B): overall morphology changed from oblong in category I to oblong with angular front zone in the other categories. Sinuate margins in category I presented entire margins after category II. Cauda was curved to ventral margin in all categories; ostium and cauda were at the same level in category I but the latter was much deeper than the former in categories II and III. Otoliths from category III presented calcareous concrescence distributed mainly on the back of the outer face. The inner face was most convex after category II. No categories presented dorsal areal depression.

Whitemouth croaker (Fig. 2C): overall morphology changed from oblong in category I to oblong with angular zone in the frontal margin in category II, and polygonal in category III. Margins sinuate in category I became irregular in category II, while in category III the ventral margin became sinuate and entire. Cauda curved to ventral border; ostium and cauda were at the same level in category I but the latter was much deeper than the former in categories II and III. The outer face presented slight undulations in category I, undulations and calcareous concrescences distributed in the centre of the outer face were present from category II onwards. The inner faces were most convex in otoliths of categories II and III. All categories presented a dorsal depression.

King Weakfish (Fig. 2D): overall morphology was oblong in all categories. Margins sinuate in category I, changed to entire dorsal margin and sinuate ventral margin in category II. Category III presented entire margins. Cauda curved to ventral margin; ostium and cauda were at the same level in category I but the latter is much deeper than the former in categories II and III. No categories presented calcareous concrescence. The inner face was rather convex from otoliths of category II onwards. All categories showed a narrow dorsal depression and a mortise in the dorsal margin, located in the back of otolith, next to the end of the cauda.

\section{Morphometric analysis}

Most parameters measured did not show significant morphometric differences between left and right otoliths: only OW in whitemouth croaker and

TABLE 1. - Differences between right and left otoliths of four sciaenid fish from the Río de la Plata estuary tested by paired $t$-test.

\begin{tabular}{|c|c|c|c|c|c|c|}
\hline Species & Standard length range $(\mathrm{mm})$ & Parameter & $\mathrm{n}$ & $\mathrm{t}$-value & df & P-value \\
\hline \multirow[t]{3}{*}{ a) C. guatuсира } & $44-127$ & OM & 90 & 1.319 & 89 & 0.1905 \\
\hline & & OW & 90 & 0.865 & 89 & 0.8645 \\
\hline & & OL & 90 & 0.766 & 89 & 0.7663 \\
\hline \multirow[t]{3}{*}{ b) $P$. brasiliensis } & $53-152$ & OM & 130 & 1.143 & 129 & 0.2551 \\
\hline & & OW & 130 & 0.865 & 129 & 0.5414 \\
\hline & & OL & 130 & 0.766 & 129 & 0.8081 \\
\hline \multirow{3}{*}{ c) M. furnieri } & $32-168$ & $\mathrm{OM}$ & 167 & 0.133 & 166 & 0.8943 \\
\hline & & $\mathrm{OW}^{*}$ & 167 & 4.149 & 166 & 0.0000 \\
\hline & & $\mathrm{OL}$ & 167 & 0.237 & 166 & 0.8128 \\
\hline \multirow[t]{3}{*}{ d) M. ancylodon } & $45-169$ & $\mathrm{OM}$ & 104 & 0.826 & 103 & 0.4107 \\
\hline & & OW & 104 & 1.895 & 103 & 0.0609 \\
\hline & & OL* & 104 & 2.938 & 103 & 0.0041 \\
\hline
\end{tabular}

* Significant differences between left and right otoliths

TABLE 2. - Relationship between fish length and fish weight in fish collected from the Río de la Plata estuary. Coefficient of determination $\left(\mathrm{R}^{2}\right)$ and sample sizes (n) are indicated. All regressions were statistically significant at $\mathrm{P}<0.05$.

\begin{tabular}{|c|c|c|c|c|c|}
\hline Species & Standard length range $(\mathrm{mm})$ & $\mathrm{n}$ & Weight range $(\mathrm{g})$ & Equation & $\mathrm{R}^{2}$ \\
\hline a) C. guatucupa & 44-127 & 90 & $1.5-37.7$ & $\mathrm{~W}=(3 \mathrm{E}-0.5) \mathrm{SL}^{2.8717}$ & 0.990 \\
\hline b) P. brasiliensis & $53-152$ & 130 & $1.8-64.4$ & $\mathrm{~W}=(5 \mathrm{E}-0.6) \mathrm{SL}^{3.2346}$ & 0.988 \\
\hline c) $M$. furnieri & $32-168$ & 167 & $0.5-75.5$ & $\mathrm{~W}=(2 \mathrm{E}-0.5) \mathrm{SL}^{2.9591}$ & 0.990 \\
\hline d) M. ancylodon & $45-149$ & 104 & $1.06-50.2$ & $\mathrm{~W}=(3 \mathrm{E}-0.6) \mathrm{SL}^{3.2952}$ & 0.985 \\
\hline
\end{tabular}


TABLE 3. - Relationships between otolith morphometric parameters and standard length (SL). Coefficient of determination $\left(\mathrm{R}^{2}\right)$ and sample sizes (n) are indicated. OL: otolith length, OW: otolith width, OM: otolith mass. All regressions were significant at $\mathrm{P}<0.05$

\begin{tabular}{lccccccc}
\hline Species & $\mathrm{n}$ & OL vs. SL & \multirow{2}{*}{$\mathrm{R}^{2}$} & $\mathrm{OW}$ vs. SL & \multirow{2}{*}{$\mathrm{R}^{2}$} & OM vs. SL & $\mathrm{R}^{2}$ \\
\hline a) . guatucupa & 90 & $\mathrm{SL}=11.894 \mathrm{OL}^{1.150}$ & 0.976 & $\mathrm{SL}=15.94 \mathrm{OW}^{1.277}$ & \multirow{2}{*}{0.953} & $\mathrm{SL}=343.42 \mathrm{OM}^{0.394}$ & 0.949 \\
b) $P$. brasiliensis & 130 & $\mathrm{SL}=8.081 \mathrm{OL}^{1.419}$ & 0.973 & $\mathrm{SL}=31.423 \mathrm{OW}^{1.512}$ & 0.437 & $\mathrm{SL}=1207.1 \mathrm{OM}^{0.645}$ & 0.974 \\
c) M. furnieri & 167 & $\mathrm{SL}=15.102 \mathrm{OL}^{1.090}$ & 0.983 & $\mathrm{SL}=23.531 \mathrm{OW}^{0.915}$ & 0.983 & $\mathrm{SL}=328.06 \mathrm{OM}^{0.3734}$ & 0.981 \\
d) M. ancylodon & 104 & $\mathrm{SL}=10.132 \mathrm{OL}^{1.155}$ & 0.977 & $\mathrm{SL}=25.271 \mathrm{OW}^{1.223}$ & 0.966 & $\mathrm{SL}=494.57 \mathrm{OM}^{0.4013}$ & 0.974 \\
\hline
\end{tabular}
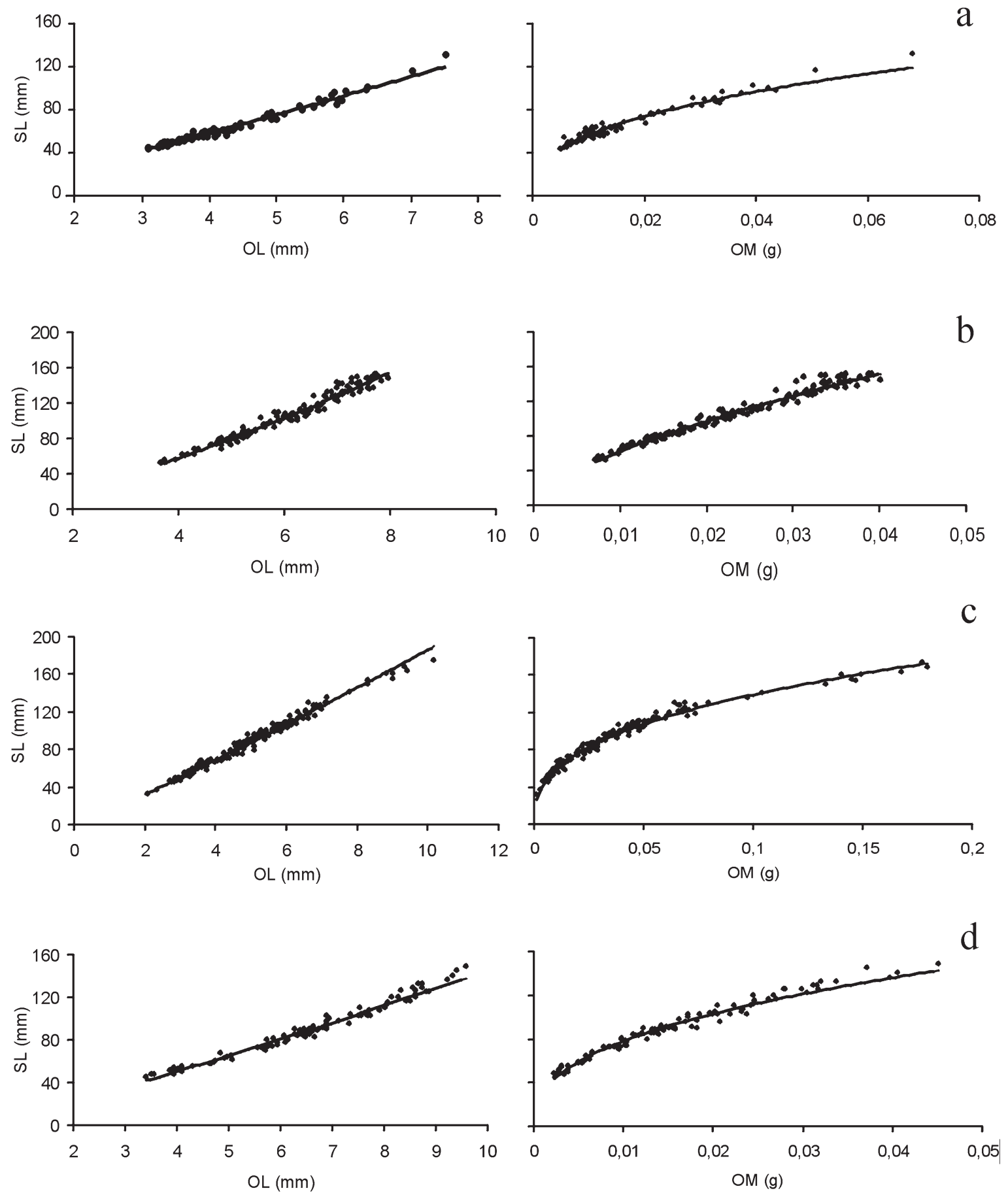

FIG. 3. - Relationships of otolith length (OL) and mass (OM) vs. standard length (SL) observed in stripped weakfish (a), banded ground drum (b), whitemouth croaker (c) and king weakfish (d) from the Río de la Plata estuary. 
TABLE 4. - Relationships between otolith morphometric parameters and Weight. Coefficient of determination $\left(\mathrm{R}^{2}\right)$ and sample sizes $(\mathrm{n})$ are indicated. OL: otolith length, OW: otolith width, OM: otolith mass. All regressions were significant at $\mathrm{P}<0.05$

\begin{tabular}{lccccccc}
\hline Species & $\mathrm{n}$ & OL vs. Weight & $\mathrm{R}^{2}$ & OW vs. Weight & \multirow{2}{*}{$\mathrm{R}^{2}$} & OM vs. Weight & $\mathrm{R}^{2}$ \\
\hline a) C. guatucupa & 90 & $\mathrm{~W}=0.0392 \mathrm{OL}^{3.2975}$ & 0.973 & $\mathrm{~W}=0.0893 \mathrm{OW}^{3.675}$ & 0.948 & $\mathrm{~W}=605.02 \mathrm{OM}^{1.131}$ & 0.949 \\
b) $P$. brasiliensis & 130 & $\mathrm{~W}=0.0045 \mathrm{OL}^{4.5805}$ & 0.965 & $\mathrm{~W}=0.395 \mathrm{OW}^{4.746}$ & 0.406 & $\mathrm{~W}=463210 \mathrm{M}^{2.0817}$ & 0.966 \\
c) . furnieri & 167 & $\mathrm{~W}=0.0596 \mathrm{OL}^{3.2297}$ & 0.980 & $\mathrm{~W}=0.2217 \mathrm{OW}^{2.9496}$ & 0.979 & $\mathrm{~W}=543.46 \mathrm{OM}^{1.1058}$ & 0.978 \\
d) M. ancylodon & 104 & $\mathrm{~W}=0.0066 \mathrm{OL}^{3.8148}$ & 0.966 & $\mathrm{~W}=0.1341 \mathrm{OW}^{4.0477}$ & 0.960 & $\mathrm{~W}=2516.1 \mathrm{OM}^{1.3274}$ & 0.967 \\
\hline
\end{tabular}
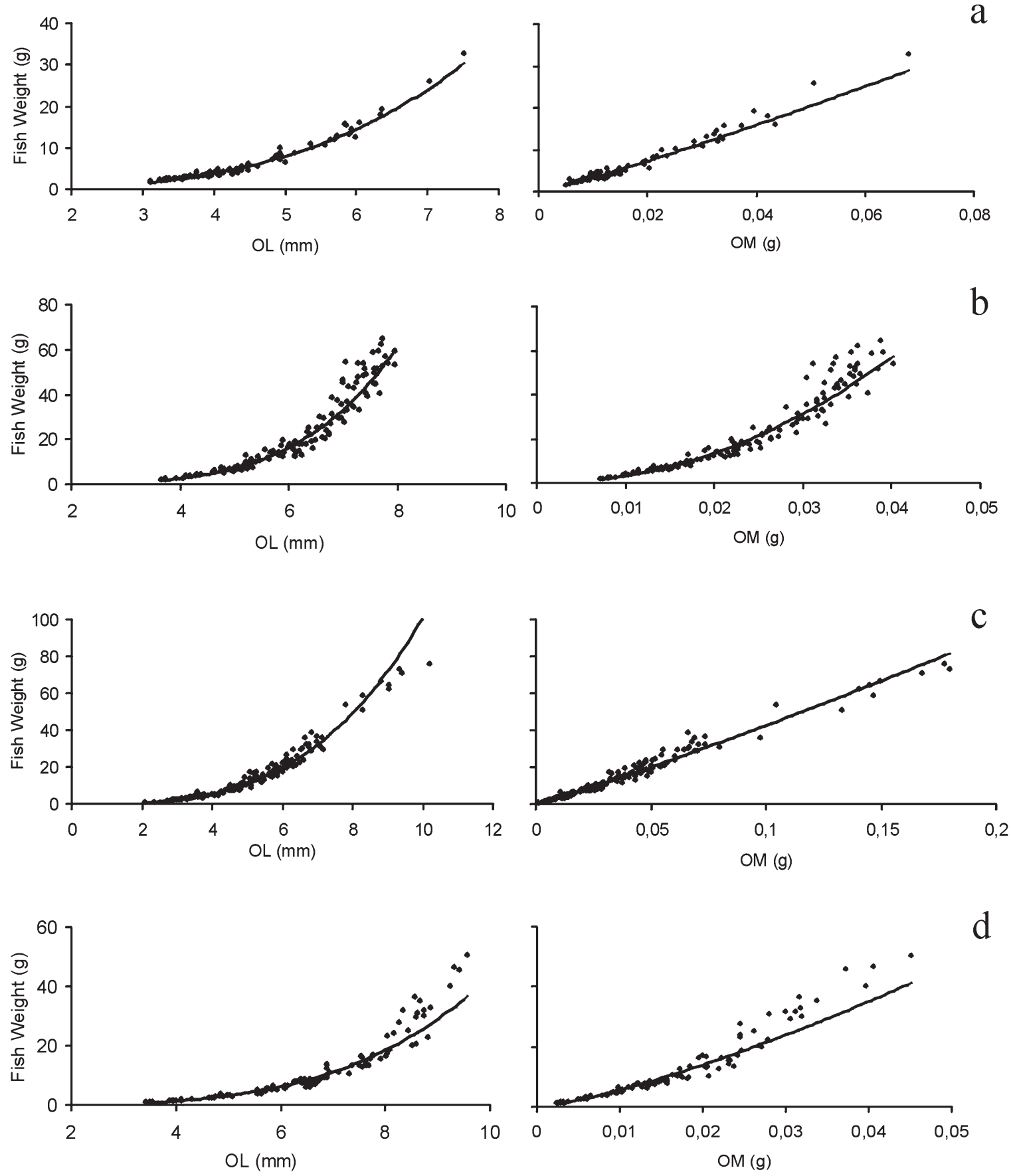

FIG. 4. - Relationships of otolith lenght (OL) and mass (OM) vs. fish weight observed in stripped weakfish (a), banded ground drum (b), whitemouth croaker (c) and king weakfish (d) from the Río de la Plata estuary. 
OL in king weakfish showed significant differences between left and right otoliths. However, these differences were on average smaller than $3 \%$ in whitemouth croaker and $1 \%$ in king weakfish (Table 1).

The relationship between fish SL and $\mathrm{W}$ was described by an exponencial equation, the coefficient of determination being higher than 0.98 in all species (Table 2).

Analysis of otolith morphometric parameters vs. SL showed that the potential regression model explained more than $95 \%$ of the variance in all species (Table 3, Fig. 3), except for the relationship between OW and SL in banded ground drum. In all species the relationships between morphometric parameters and $\mathrm{W}$ were described by the potential regression model, which explained $94 \%$ of the variance. Only banded ground drum showed no significant accuracy in the OW vs. W relationship (Table 4, Fig. 4).

\section{DISCUSSION}

In agreement with Volpedo and Echeverría (1999) for whitemouth croaker, the sagittae morphology of other juvenile sciaenid species major strong changes during their development. Overall morphology changed from polygonal to oblong in stripped weakfish, oblong to oblong with angular front zone in banded ground drum, oblong to polygonal in whitemouth croaker, but remained with a generally oblong shape in king weakfish. According to Volpedo and Echeverría (1999), the variations may be due to the way in which the $\mathrm{CaCO}_{3}$ is deposited during the sagittae development. While in small otoliths $\mathrm{CaCO}_{3}$ is uniformly deposited, as the otolith grows the deposition of this salt occurs mainly in the front-back axis, resulting in a large elongation of these otoliths.

All species showed ostium and cauda at the same level in category I, the latter being much deeper than the former in categories II and III. This agreed with the observations of Volpedo and Echeverría (1999) for juvenile and adult whitemouth croakers, and of Baldás et al. (1997) in adult whitemouth croakers, stripped weakfish, king weakfish, banded ground drums and Argentine croakers (Umbrina canosai Berg, 1895). The presence of a dorsal depression area on the inner face, dorsally accompanying the sulcus, was observed in all analysed sagittae of stripped weakfish, king weakfish and whitemouth croaker. These results were in agreement with those reported by Volpedo and Echeverría (1999) for whitemouth croaker and Chao (1978) for Cynoscion spp. We also agree with the position of a dorsal depression area in stripped weakfish reported by Corrêa and Vianna (1993).

A calcareous concrescence on the outer face of category III sagittae was strongly developed in stripped weakfish, whitemouth croaker and banded ground drum. Saenz Echeverría (1950) reported pearls or little smooth pebbles as calcareous concrescences in juvenile fishes, changing to prominent protuberances in otoliths of adult individuals in sciaenids from the Sahara Coast. The presence of crestlike, bloblike projections or granulations in Western Atlantic sciaenids was reported for Chao (1978). Baldás et al. (1997) reported the occurrence of these calcareous concrescences in adult whitemouth croakers, banded ground drums and Argentine croakers. Volpedo and Echeverría (1999) argued that the differential pattern of calcium carbonate deposition and the presence of calcareous concrescence in juvenile (120 to $300 \mathrm{~mm}$ total length [TL]) and adult whitemouth croakers could be due to changes in physical and chemical parameters in different habitats. Therefore, the distinctive characteristics of the otoliths in the Sciaenidae is the absence of the rostrum, excisura and antirostrum (Torno, 1976), the presence of cauda and ostium with different textures, cauda curved to ventral margin, and much deeper than the ostium (Corrêa and Vianna, 1993), the presence of calcareous concrescence in the inner face (Baldás et al., 1997) and a dorsal depression on the inner face of the former otolith stages (this study).

All equations relating otolith variables to fish standard length and fish weight for juvenile sciaenid specimens studied explained a very large proportion of the variance in the data (see Table 2); these results are in agreement with those published by Haimovici and Velasco (2000) for the same sciaenid species from southern Brazil. Also, our data on OM vs. SL of banded ground drum fall in the range of the South Brazilian population of this species (Vargas, 1976). Analysing the morphometric relationships, we concluded that otolith length and otolith mass are good indicators of fish standard length and fish weight in all species. If otolith length is used to estimate fish length, the potential regression explained more than $97 \%$ of data variation in all species. If otolith mass is used, potential regression explained more than $97 \%$ of the variation in banded ground drum, king weakfish and whitemouth croaker and more than 
95\% in stripped weakfish. Baldás et al. (1997) described the relationship between otolith length and fish total length by using potential models in stripped weakfish (50-600 mm TL) and linear models in whitemouth croaker (140-370 mm TL). Also, Torno (1976) developed linear models to describe the same relationship in king weakfish (230-350 mm TL). It was impossible to compare our model with those from the literature due to differences in the size distribution of the fish sampled and the different morphometric measurements taken. When otolith length and otolith mass were used to estimate fish weight, the coefficient of determination $\left(\mathrm{R}^{2}\right)$ in all species was slightly smaller than the respective values of fish weight estimated from fish length (see Tables 2 and 4). However, the straight estimation of fish weight by using otolith length or otolith mass could avoid the introduction of additional errors due to the use of two regressions instead of only one.

\section{ACKNOWLEDGEMENTS}

We thank Luis Lucifora for his comments on an earlier version of the manuscript and Natalia Hozbor and Andrés Jaureguizar for their assistance. We also thank two anonymous reviewers for their helpful comments. The Antorchas Foundation (grant A13672/1-4) supported this work.

\section{REFERENCES}

Acha, E.M., H. Mianzán, C.A. Lasta and R.A. Guerrero. - 1999. Estuarine spawning of the whitemouth croaker Micropogonias furnieri (Pisces: Sciaenidae), in the Río de la Plata, Argentina. Mar. Freshwater Res., 50: 57-65.

Baldás, M.I., G. Pérez Macri, A.V. Volpedo and D.D. Echeverría. 1997. Morfología de la Sagitta de peces marinos de la costa bonaerense de la Argentina I: Carangidae, Sciaenidae, Mullidae. Atlântica, Río Grande, 19: 99-112.

Brownell, R.L. Jr. - 1975. Progress report on the biology of the franciscana dolphin, Pontoporia blainvillei, in Uruguayan waters. J. Fish. Res. Board. Can., 32: 1073-1078.

Chao, L.N. 1978. A basis for classifying Western Atlantic Sciaenidae (Teleostei: Perciformes). NOAA Tech. Rep. NMFS Circ. 415, 64.

Corrêa, M.F.M. and M.S. Vianna. - 1993. Catálogo de otólitos de sciaenidae (Osteichthyes-Perciformes) do litoral do Estado do Paraná, Brasil. Nerítica, Curitiba, 7: 13-41.

Cousseau, M.B. - 1985. Los peces del Río de la Plata y su frente marítimo. In: A. Yañez-Arancibia (ed.) Fish Community Ecology in Estuaries and Coastal Lagoons: Towards an Ecosystem Integration, Chap. 24: 515-534. UNAM Press México.

Everson, I., B. Bendall and A. Murray. - 1999. Otolith and body size relationships in the Mackerel Icefish (Champsocephalus gunnari). CCAMLR, 6: 117-123.

Favero, M., M.S. Bó, M.P. Silva and C. García Mata. - 2000a. Food and feeding biology of the South American tern during nonbreeding season. Waterbirds, 23: 125-129.

Favero, M., M.P. Silva and L. Mauco. - 2000b. Diet of royal and Sandwich terns during austral winter at Buenos Aires Province, Argentina. Ornitol. Neotr., 11: 259-262.

Favero, M., R. Mariano y Jelicich, M.P. Silva, M.S. Bó and C. García Mata. - 2001. Food and feeding biology of black skimmer in Argentina: evidence supporting offshore feeding in nonbreeding grounds. Waterbirds, 24: 413-418.

Gamboa, D.A. - 1991. Otolith size versus weight and body-length relationships for eleven fish species of Baja California, Mexico. Fish. Bull., 89: 701-706.

Granadeiro, J.P. and M.A. Silva - 2000. The use of otoliths and vertebrae in the identification and size-estimation of fish in predator-prey studies. Cybium, 24(4): 383-393.

Haimovici, M. and G. Velasco. - 2000. Length-weight relationship of marine fishes from Southern Brazil. Naga, 23(1): 19-23.

Harvey, J.T., T.R. Loughlin, M.A. Pérez and D.S. Oxman. -2000. Relationship between fish size and otolith length for 63 species of fishes from the Eastern North Pacific Ocean. U.S. Dep. Commer., NOAA Tech. Rep. NMFS 150, 36 pp.

Jobling, M. and A. Breiby. - 1986. The use and abuse of fish otoliths in studies of feeding habits of marine piscivores. Sarsia, 71: 265-274.

Lasta, C.A. - 1995. La Bahía de Samborombón: zona de desove y cría de peces. Doctoral Thesis, Universidad Nacional de la Plata, Argentina. 304 pp.

Mauco, L., M. Favero and M.S. Bó. - 2001. Food and feeding of the common tern (Sterna hirundo) in Samborombón Bay, Buenos Aires, Argentina. Waterbirds, 24: 89-96.

Menni, R.C., R.A. Ringuelet and R.A. Arámburu. - 1984. Peces Marinos de la Argentina y Uruguay. Editorial Hemisferio Sur, Buenos Aires, $359 \mathrm{pp}$.

Reid, K. - 1996. A guide to the use of otoliths in the study of predators at South Georgia. British Antarctic Survey, Natural Environment Research Council, Cambridge, UK.

Rodríguez, D.H. - 1996. Biología y Ecología de los Pinnípedos del Sector Bonaerense. Doctoral Thesis, Universidad Nacional de Mar del Plata, Argentina. $351 \mathrm{pp}$.

Saenz Echeverría, J. - 1950. Notas sobre otolitos de peces procedentes de las costas del Sahara. Bol. Inst. Esp. Oceanogr., 27: $1-20$.

Silva, M.P., R. Bastida and C.A. Darrieu. - 2000. Ecología Trófica de la Gaviota Cocinera (Larus dominicanus) en zonas costeras de la Provincia de Buenos Aires. Ornitol. Neotr., 11: 331-339.

Tollit, D.J., M.J. Steward, P.M. Thompson, G.J. Pierce, M.B. Santos and S. Hughes. - 1997. Species and size differences in the digestion of otoliths and beaks: implications for estimates of pinniped diet composition. Can. J. Fish. Aquat. Sci., 54: 105-1197

Torno, A. - 1976. Descripción y comparación de los otolitos de algunas familias de peces de la plataforma argentina. Rev. Mus. Arg. Cs. Nat. "Bernardino Rivadavia", 12(4): 1-18.

Vargas, C.P. - 1976. Geographic differentiation of Paralonchurus brasiliensis (Steindachner, 1875) between the latitudes $23^{\circ} 30^{\prime} \mathrm{S}$ (Ubatuba, S.P.) and $32^{\circ} \mathrm{S}$ (Barra do Rio Grande, R.S.), Brazil. Rev. Trav. Inst. Pêches Marit. 40(3-4): 775-779.

Volpedo, A.V. and D.D. Echeverría. - 1999. Morfología de los otolitos sagittae de juveniles y adultos de Micropogonias furnieri (Desmarest, 1823) (Sciaenidae). Thalassas, 15: 19-24.

Volpedo, A.V. and D.D. Echeverría. - 2000. Catálogo y claves de otolitos para la identificación de peces del Mar Argentino 1. Peces de importancia económica. Editorial Dunken, Buenos Aires.

White, M.G. - 1991. Age Determination in Antarctic Fish. In: G. Di Prisco, B. Maresca and B. Tota (eds.). Biology of Antarctic Fish, pp. 87-100. Springer-Verlag, New York.

Scient. ed.: G. Pequeño 